\title{
VITALITAS BAHASA SALEMAN DI NEGERI SALEMAN
}

The Vitality of Saleman Language in Saleman Village

\author{
Mardi Nugroho \\ Badan Pengembangan dan Pembinaan Bahasa \\ mardinugroho16@gmail.com
}

Naskah Diterima Tanggal 21 Maret 2020-Direvisi Akhir Tanggal 12 November 2020-Disetujui Tanggal 7 Desember 2020 doi: https://doi.org/10.26499/rnh.v9i2.2938

\begin{abstract}
Abstrak
Penelitian ini bertujuan untuk menginvestigasi vitalitas bahasa Saleman di Negeri Saleman dan berusaha menjelaskan vitalitas itu berdasarkan faktor-faktor yang menentukan vitalitas bahasa. Manfaat penelitian ini ialah memberi informasi berharga bagi Badan Pengembangan dan Pembinaan Bahasa serta pemerintah daerah untuk menyusun skala prioritas pelindungan bahasa daerah. Selain itu, penjelasan mengenai vitalitas bahasa Saleman berdasarkan faktor-faktor yang menentukan vitalitas bahasa dapat dijadikan acuan dalam kegiatan konservasi dan revitalisasi bahasa Saleman. Penelitian ini menggunakan metode campuran, yaitu metode kuantitatif dan metode kualitatif. Metode yang dominan ialah metode kuantitatif, pengumpulan data dilakukan dengan kuesioner. Metode kualitatif dimanfaatkan untuk membantu memberikan penjelasan dari temuan metode kuantitatif, pengumpulan data dilakukan dengan wawancara. Pengolahan data penelitian yang berupa tanggapan responden terhadap kuesioner dilakukan secara kuantitatif. Sebelum pengolahan data, dilakukan pengeditan data dan pengodean data. Analisis data hasil wawancara dilakukan secara kualitatif dengan langkah-langkah reduksi data, penyajian data, dan penarikan kesimpulan. Hasil penelitian menunjukkan bahwa vitalitas bahasa Saleman di Negeri Saleman dalam tingkat mengalami kemunduran. Empat faktor yang menentukan vitalitas bahasa, yaitu kontak bahasa, ranah penggunaan bahasa, dokumentasi, dan respons terhadap tantangan baru nilai indeksnya lebih rendah daripada nilai indeks total. Keempat faktor itulah yang menjadi penyumbang utama vitalitas bahasa Saleman di Negeri Saleman rendah, yaitu dalam tingkat mengalami kemunduran.
\end{abstract}

Kata-kata kunci: vitalitas bahasa Saleman, Negeri Saleman, Maluku

\begin{abstract}
This study aims to investigate the vitality of the Saleman language in Saleman village and try to explain this vitality based on the factors that determine the vitality of the language. The benefit of this research is, provides valuable information for the National Agency for Language Development and Cultivation, as well as local governments in setting priorities for local language protection. Besides, an explanation of the vitality of the Saleman language, based on the factors that determine the vitality of the language, can use a reference in conservation and revitalization activities for the Saleman language. This research used mixed methods, namely quantitative and qualitative methods. The dominant method is quantitative, data collection done through a questionnaire. Qualitative methods used to help explain the findings of quantitative methods, data collection done by interview. Research data processing in the form of respondents' responses to the questionnaire carried out quantitatively. Before data processing, data editing, and data coding performed. The data analysis conducted qualitatively with the steps of data reduction from the interview, data display, and conclusion drawing. The results showed that the vitality of the Saleman language in the Saleman Village eroding. The four factors that determine the vitality of language, namely language contact, the realm of language use, documentation, and responses to new challenges, have lower index scores than the total index value. These four factors are the main contributors that show the vitality of the Saleman language in Saleman VIllage is low. It might say they are in a level of eroding.
\end{abstract}

Keywords: the vitality of the Saleman language, Saleman Village, Maluku

How to Cite: Nugroho, Mardi. (2020). Vitalitas Bahasa Saleman di Negeri Saleman. Ranah: Jurnal Kajian Bahasa. 9(2). 260-271. doi: https://doi.org/10.26499/rnh.v9i2.2938 


\section{PENDAHULUAN}

Kekayaan budaya di Indonesia berupa bahasa daerah berjumlah ratusan. Tim Pemetaan Bahasa (2017) telah menginventarisasi dan mendeskripsikan 652 bahasa daerah di Indonesia. Ratusan bahasa daerah itu harus dilindungi sebagaimana disebutkan dalam Pasal 42 UndangUndang Republik Indonesia Nomor 24 Tahun 2009 (Badan Pengembangan dan Pembinaan Bahasa, 2011).

Pelindungan bahasa-bahasa daerah dilakukan antara lain untuk meminimalkan pergeseran bahasa dan kepunahan bahasa daerah. Hal itu karena sudah banyak penelitian yang menginformasikan adanya pergeseran dan kepunahan bahasa daerah di Indonesia. Beberapa di antaranya ialah penelitian Katubi (2011), yaitu pergeseran bahasa dalam masyarakat Kui; Mardikantoro (2012), yaitu pergeseran bahasa pada masyarakat Samin; Sahril (2018), yaitu pergeseran bahasa daerah pada anak-anak di Kuala Tanjung, Sumatera Utara.

Pelindungan bahasa daerah di Indonesia yang berjumlah ratusan itu tidak dapat dilaksanakan secara serentak karena dana dan sumber daya manusia yang terbatas. Oleh karena itu, perlu dibuat skala prioritas atau dibuat pengelompokan bahasa, yaitu bahasabahasa daerah mana yang lebih mendesak untuk dilindungi dan bahasa-bahasa daerah mana yang kurang mendesak untuk dilindungi. Salah satu cara yang dapat membantu untuk membuat pengelompokan bahasa itu ialah dengan kajian vitalitas (daya hidup) bahasa.

Di Maluku ada bahasa daerah yang dinamakan bahasa Saleman (Tim Pemetaan Bahasa, 2017:171). Nama lain untuk bahasa Saleman ialah bahasa Sawai dan bahasa Koa-Koa. Collins (2018:80) menyebutnya sebagai bahasa Sawai dan menurutnya bahasa itu dituturkan di Negeri Pasanea, Saleman, Sawai, dan Besi, serta dahulu juga dituturkan di Negeri Wahai. Sejauh penelusuran penulis, belum ada laporan mengenai kajian vitalitas bahasa Saleman.

Berdasarkan latar belakang di atas, masalah dalam penelitian ini ialah "bagaimanakah vitalitas bahasa Saleman di Negeri Saleman?” Tujuan penelitian ini ialah untuk mengetahui vitalitas bahasa Saleman di Negeri Saleman dan berusaha menjelaskan vitalitas itu berdasarkan faktor-faktor yang menentukan vitalitas bahasa.

Sudah ada peneliti yang melakukan penelitian vitalitas bahasa daerah. Beberapa di antaranya ialah Wibowo; Winarti; Aritonang; Candrasari; Wagiati, Wahya, dan Riyanto; Maricar dan Ety; Nugroho; Inayatusshalihah; Firdaus; dan Setiawati dkk. Wibowo (2014) telah melakukan penelitian vitalitas bahasa Enggano. Hasilnya ialah bahasa Enggano di Pulau Enggano, Bengkulu pada level mengalami kemunduran. Winarti (2014) telah melakukan 
penelitian vitalitas bahasa Bahonsuai. Hasilnya ialah vitalitas bahasa Bahonsuai di Desa Bahonsuai, Sulawesi Tengah pada level berpotensi mengalami kemunduran. Aritonang (2013) melakukan penelitian dengan judul "Vitalitas Bahasa Seget: Kajian ke Arah Pemetaan Vitalitas Bahasa Daerah". Selain itu, Aritonang (2016) juga melakukan penelitian terhadap bahasa Talondo dengan judul "Kriteria Vitalitas Bahasa Talondo". Hasilnya ialah vitalitas bahasa Talondo masuk kriteria mengalami kemunduran. Candrasari (2017) telah menyusun disertasi dengan judul "Bahasa Devayan di Pulau Simeuleu: Kajian Vitalitas Bahasa". Hasilnya ialah vitalitas bahasa Devayan di Pulau Simeuleu pada level 6b menurut skala EGIDS, yaitu terancam punah. Wagiati, Wahya, dan Riyanto (2017) melakukan penelitian mengenai vitalitas bahasa Sunda di Kabupaten Badung. Maricar dan Ety (2017) melakukan penelitian dengan judul "Vitalitas Bahasa Ternate di Pulau Ternate". Nugroho (2018) telah melakukan penelitian vitalitas bahasa Yalahatan. Kajian itu menunjukkan bahwa vitalitas bahasa Yalahatan berada pada level mengalami kemunduran. Inayatusshalihah (2018) telah melakukan penelitian vitalitas bahasa Buru di Desa Wamlana, Pulau Buru, Provinsi Maluku. Kesimpulannya ialah bahasa Buru di Desa Wamlana dapat dikatakan berada pada tingkat ke-3 dari skala keterancaman UNESCO, yaitu definitely endangered. Firdaus (2018) melakukan penelitian dengan judul "Tekanan Kepunahan Bahasa Suwawa: Analisis Tingkat Daya Hidup Bahasa". Hasilnya ialah bahasa Suwawa dalam kondisi stabil, tetapi terancam punah. Setiawati dkk. (2019) melakukan penelitian dengan judul "Vitalitas Bahasa, Diglosia, dan Ketirisannya: Pemertahanan Bahasa Manduro di Desa Manduro, Kecamatan Kabuh, Kabupaten Jombang, Jawa Timur”. Hasilnya ialah bahasa Manduro di Desa Manduro dalam kondisi stabil-mantap, tetapi berpotensi terancam. Diglosia terdapat pada ranah keluarga, kerabat, pertetanggaan, dan pertemanan. Ketirisan diglosia terjadi pada ranah pertemanan.

Seluruh penelitian vitalitas bahasa yang telah dilakukan oleh para peneliti itu bersama dengan penelitian vitalitas bahasa yang penulis laporkan ini bermanfaat karena setiap bahasa daerah idealnya diteliti vitalitasnya. Manfaat penelitian vitalitas bahasa yang telah dilakukan oleh para peneliti itu bersama dengan penelitian ini ialah untuk menyusun peta vitalitas bahasa-bahasa daerah di Indonesia. Peta vitalitas itu memberi informasi berharga bagi Badan Pengembangan dan Pembinaan Bahasa serta pemerintah daerah untuk menyusun skala prioritas pelindungan bahasa daerah. Selain itu, hasil penelitian ini yang berupa penjelasan mengenai vitalitas bahasa Saleman berdasarkan faktor-faktor penentu vitalitas bahasa dapat dijadikan acuan kegiatan konservasi dan revitalisasi bahasa Saleman. Sebagai contoh bahasa 
Saleman di Negeri Saleman hanya digunakan dalam satu atau dua ranah, pihak-pihak yang peduli terhadap pelindungan bahasa Saleman dapat berusaha menambah ranah penggunaan.

\section{LANDASAN TEORI}

Penelitian ini berlandaskan teori sosiolinguistik. Teori-teori yang penting untuk dikemukakan dalam penelitian ini ialah yang tertuang dalam tulisan Ibrahim, UNESCO, Badan Pengembangan dan Pembinaan Bahasa, Chaer, Lukman, dan Malabar.

Ibrahim (2009:97) mengungkapkan kembali rumusan Grimes perihal enam tingkat keterancaman bahasa, yaitu critically endangered, severely endangered, endangered, eroding, stable but threatened, dan safe. Dalam sebuah konsinyasi di Bogor yang dihadiri oleh pakar serta pejabat dan staf Pusat Bahasa, dengan mempertimbangkan rumusan Grimes di atas, Pusat Bahasa merumuskan tingkat vitalitas bahasa yang diukur berdasarkan nilai rerata (indeks) yaitu

(1) sangat terancam $(0.0--0.2)$;

(2) terancam $(0.21-0.4)$;

(3) mengalami kemunduran $(0.41-0.6)$;

(4) rentan $(0.61-0.8)$; dan

(5) $\operatorname{aman}(0.81-1)$.

Tingkat vitalitas bahasa yang dirumuskan oleh Pusat Bahasa itulah yang diikuti dalam penelitian ini.

UNESCO (2011:3) telah mengidentifikasi sembilan faktor untuk menentukan tingkat vitalitas suatu bahasa, yaitu (1) intergenerational language transmission, (2) absolute number of speakers, (3) proportion of speakers within the total population, (4) shifts in domains of language use, (5) response to new domains and media, (6) availabillity of materials for language education and literacy, (7) governmental and institutional language attitudes and policies including official status and use, (8) community members' attitudes toward their own language, dan (9) amount and quality of documentation. Berdasarkan kesembilan faktor itu, Tim Konservasi dan Revitalisasi (2017) telah menyusun kuesioner untuk menentukan tingkat vitalitas suatu bahasa. Kuesioner tersebut berisi sembilan puluh butir pernyataan. Dalam pengumpulan data penelitian ini penulis menggunakan kuesioner yang disusun Tim Konservasi dan Revialisasi Badan Pengembangan dan Pembinaan Bahasa itu.

Tulisan Chaer (2010) memberikan pemahaman dan wawasan penulis serta memberikan pedoman bagi penulis dalam penelitian ini. Sekadar contoh, Chaer 
mengutarakan peristiwa-peristiwa kebahasaan yang mungkin terjadi sebagai akibat kontak bahasa, yaitu bilingualisme, diglosia, alih kode, campur kode, interferensi, integrasi, dan pergeseran bahasa. Peristiwa-peristiwa kebahasaan itu dan hal-hal lain yang terkait dijelaskan pada halaman 84-160. Selain itu, buku tulisan Lukman (2012) berjudul Vitalitas Bahasa: Pergeseran dan Pemertahanan Bahasa serta tulisan Malabar (2015), khususnya pembahasan mengenai pergeseran dan pemertahanan bahasa, juga memberikan pemahanan, wawasan, dan pedoman bagi penulis.

\section{METODE PENELITIAN}

Penelitian ini menggunakan metode campuran, yaitu metode kuantitatif dan metode kualitatif. Metode yang dominan digunakan ialah metode kuantitatif; pengumpulan datanya dilakukan dengan kuesioner, sedangkan metode kualitatif dimanfaatkan untuk membantu memberikan penjelasan dari temuan metode kuantitatif. Pengumpulan data dengan metode ini dilakukan melalui wawancara. Pengumpulan data dilakukan di Negeri Saleman, Kecamatan Seram Utara Barat, Kabupaten Maluku Tengah, Provinsi Maluku.

Penelitian ini menggunakan kuesioner yang disusun oleh Pusat Pengembangan dan Pelindungan Bahasa dan Sastra yang sudah diuji validitas dan realibilitasnya. Kuesioner digunakan untuk mengukur tingkat vitalitas bahasa Saleman (berupa indeks total) dan indeks per faktor yang menentukan vitalitas bahasa. Kuesioner diberikan kepada responden, yaitu penutur bahasa Saleman di Negeri Saleman yang dijadikan sampel penelitian. Jumlah responden sebanyak seratus orang. Responden diupayakan mewakili keragaman sosial, yaitu dari segi jenis kelamin, usia, dan pendidikan. Adapun komposisi responden penelitian ini dapat dilihat pada tabel berikut ini.

Tabel 1.

Deskripsi Komposisi Responden

\begin{tabular}{lll}
\hline \multicolumn{2}{c}{ Komposisi Responden menurut Jenis Kelamin, Usia, } & \\
dan Pendidikan & Jumlah Responden \\
\hline \multirow{2}{*}{ Jenis Kelamin } & laki-laki & 39 \\
\cline { 2 - 3 } & perempuan & 61 \\
\hline \multirow{2}{*}{ Usia } & $<25$ tahun & 22 \\
\cline { 2 - 3 } & $25-50$ tahun & 69 \\
\cline { 2 - 3 } & $>25$ tahun & 9 \\
\hline \multirow{2}{*}{ Pendidikan } & SD atau sederajat & 20 \\
\cline { 2 - 3 } & SMP/SMA atau sederajat & 61 \\
\cline { 2 - 3 } & perguruan tinggi & 19 \\
\hline
\end{tabular}


Pengisian kuesioner dilakukan di balai Negeri Saleman dan diatur sedemikian rupa untuk mendapakan data sebaik-baiknya, misalnya pengisian kuesioner dilakukan secara bertahap (untuk mengatur jumlah responden yang datang bersamaan), sehingga pengisian kuesioner bisa terkendali. Selain itu, penulis juga bekerja sama dengan aparat negeri dan tokoh pemuda setempat untuk memilih responden sesuai dengan kriteria yang telah ditetapkan serta untuk membantu mengenali dan mengendalikan responden.

Pengolahan data penelitian yang berupa tanggapan responden terhadap kuesioner dimulai dengan pengeditan data, pengodean data, dan pemrosesan. Pengeditan data dilakukan dengan maksud untuk memastikan bahwa tanggapan yang diberikan sesuai dengan perintah dan petunjuk pelaksanaan. Pengodean data dilakukan dengan tujuan untuk memudahkan proses pengolahan data. Pemrosesan data dimulai dengan melakukan penginputan data dalam bentuk tabulasi pada program excel. Selanjutnya, data diolah secara kuantitatif.

Wawancara dilakukan untuk membantu memberikan penjelasan dari temuan metode kuantitatif. Yang diwawancarai ialah warga masyarakat Saleman, pemerintah setempat, tokoh masyarakat, dan pihak-pihak lain yang dipandang dapat memberikan data dan informasi. Wawancara dilakukan secara tidak terstruktur dan dilakukan melalui tatap muka. Ada wawancara yang dilakukan dengan meminta waktu khusus untuk wawancara, ada yang dilakukan tanpa meminta waktu khusus, misalnya pada saat sebagian warga masyarakat duduk-duduk santai di masjid sambil menunggu azan isya. Garis besar pertanyaannya ialah sembilan faktor yang menentukan tingkat vitalitas suatu bahasa yang telah diidentifikasi oleh UNESCO seperti telah disebutkan sebelumnya.

Analisis data hasil wawancara dilakukan dengan langkah-langkah reduksi data, penyajian data, dan penarikan kesimpulan. Analisis data dilakukan pada saat pengumpulan data (saat wawancara) dan setelah selesai pengumpulan data. Dalam penarikan kesimpulan, ada kesimpulan yang bersifat sementara dahulu untuk diverifikasi.

\section{PEMBAHASAN}

Untuk mengetahui vitalitas bahasa Saleman di Negeri Saleman, responden diberi kuesioner. Kuesioner terdiri atas sepuluh kelompok. Kelompok I ialah kelompok jumlah penutur, sebanyak 2 butir. Kelompok II ialah kelompok kontak bahasa, sebanyak 7 butir. Kelompok III ialah kelompok bilingualisme, sebanyak 15 butir. Kelompok IV ialah kelompok posisi dominan masyarakat penutur, sebanyak 4 butir. Kelompok V ialah kelompok ranah penggunaan bahasa, sebanyak 14 butir. Kelompok VI ialah kelompok sikap bahasa, sebanyak 
11 butir. Kelompok VII ialah kelompok regulasi, sebanyak 12 butir. Kelompok VIII ialah kelompok pembelajaran, sebanyak 9 butir. Kelompok IX ialah kelompok dokumentasi, sebanyak 8 butir. Kelompok X ialah kelompok respons terhadap tantangan baru, sebanyak 8 butir. Data yang berupa tanggapan responden terhadap pernyataan tersebut ditabulasi dan diolah secara kuantitatif. Berikut ini secara berturut-turut dipaparkan hasil pengolahan data yang berupa deskripsi frekuensi tanggapan responden terhadap butir-butir pernyataan dan vitalitas bahasa Saleman di Negeri Saleman.

\section{Frekuensi Tanggapan Responden terhadap Butir-Butir Pernyataan}

Karena keterbatasan ruang, pada pembahasan ini hanya ditampilkan tanggapan responden dari beberapa butir pernyataan dalam kuesioner.

Tabel 2.

Frekuensi Tanggapan Responden terhadap Butir Pernyataan Kelompok Kontak Bahasa

\begin{tabular}{lcc}
\hline \multicolumn{1}{c}{ Butir Pernyataan } & $\begin{array}{c}\text { Jumlah } \\
\text { Tanggapan "ya" }\end{array}$ & $\begin{array}{c}\text { Jumlah Tanggapan } \\
\text { "tidak" }\end{array}$ \\
\hline $\begin{array}{l}\text { Masyarakat suku saya dapat menikmati siaran } \\
\text { televisi nasional }\end{array}$ & 84 & 16 \\
\hline $\begin{array}{l}\text { Daerah ini sukar dijangkau dari daerah lain dan } \\
\text { dari kota }\end{array}$ & 36 & 64 \\
\hline $\begin{array}{l}\text { Penutur bahasa daerah ini sering bepergian ke } \\
\text { daerah lain yang berbeda bahasa }\end{array}$ & 59 & 41 \\
\hline
\end{tabular}

Terhadap pernyataan "Masyarakat suku saya dapat menikmati siaran televisi nasional" 84 responden (84\%) merespons "ya". Itu berarti berdasarkan 84\% responden, terjadi kontak bahasa pada suku mereka, karena biasanya televisi nasional disiarkan dalam bahasa Indonesia. Terhadap pernyataan "Daerah ini sukar dijangkau dari daerah lain dan dari kota" 64 responden $(64 \%)$ merespons "tidak". Itu berarti berdasarkan $64 \%$ responden, mudah terjadi kontak bahasa pada daerah mereka, karena kalau suatu daerah mudah dijangkau dari kota, mudah pula terjadi kontak bahasa. Penting ditambahkan informasi bahwa Negeri Saleman dekat dengan jalan raya yang menghubungkan ibu kota Kabupaten Maluku Tengah (Masohi) dengan ibu kota Kabupaten Seram Bagian Timur (Bula). Selain itu, jalan masuk dari jalan raya Masohi-Bula ke Negeri Saleman sudah bagus. Terhadap pernyataan "Penutur bahasa daerah ini sering bepergian ke daerah lain yang berbeda bahasa", 59 responden (59\%) merespons "ya". Itu berarti berdasarkan 59\% responden, mudah terjadi kontak bahasa pada bahasa mereka. Penting ditambahkan informasi bahwa penutur bahasa Saleman yang bepergian ke daerah lain yang berbeda bahasa ialah untuk keperluan bersekolah (di Negeri Saleman tidak ada SMA atau perguruan tinggi, banyak warga Saleman yang bersekolah dan 
kuliah di kota), menjual hasil kebun (sebagian besar warga Saleman ialah berkebun), berbelanja, dan lain-lain.

Berikut ini dua tabel frekuensi tanggapan responden terhadap dua butir pernyataan kelompok ranah penggunaan bahasa.

Tabel 3.

Frekuensi Tanggapan Responden terhadap Butir Pernyataan Kelompok Ranah Penggunaan Bahasa

\begin{tabular}{lcc}
\multicolumn{1}{c}{ Butir Pernyataan } & $\begin{array}{c}\text { Jumlah } \\
\text { Tanggapan "ya" }\end{array}$ & $\begin{array}{c}\text { Jumlah Tanggapan } \\
\text { "tidak" }\end{array}$ \\
\hline $\begin{array}{l}\text { Bahasa daerah ini saya gunakan ketika saya } \\
\text { berurusan dengan petugas kesehatan }\end{array}$ & 10 & 90 \\
\hline $\begin{array}{l}\text { Bahasa daerah ini saya gunakan untuk berdoa } \\
\text { kepada Tuhan Yang Maha Esa }\end{array}$ & 30 & 70 \\
\cline { 2 - 2 }
\end{tabular}

Terhadap pernyataan "Bahasa daerah ini saya gunakan ketika saya berurusan dengan petugas kesehatan", 90 responden (90\%) merespons "tidak". Itu berarti menurut 90\% responden, bahasa Saleman tidak mereka gunakan ketika berurusan dengan petugas kesehatan. Terhadap pernyataan "Bahasa daerah ini saya gunakan untuk berdoa kepada Tuhan Yang Maha Esa", 70 responden (90\%) merespons "tidak". Itu berarti menurut 70\% responden, bahasa Saleman tidak mereka gunakan ketika berdoa kepada Tuhan Yang Maha Esa.

Berikut ini dua tabel frekuensi tanggapan responden terhadap butir-butir pernyataan kelompok sikap bahasa.

Tabel 4.

Frekuensi Tanggapan Responden terhadap Butir Pernyataan Kelompok Sikap Bahasa

\begin{tabular}{lcc}
\multicolumn{1}{c}{ Butir Pernyataan } & $\begin{array}{c}\text { Jumlah } \\
\text { Tanggapan "ya" }\end{array}$ & $\begin{array}{c}\text { Jumlah Tanggapan } \\
\text { "tidak" }\end{array}$ \\
\hline Saya bangga terhadap bahasa daerah ini & 97 & 3 \\
\hline $\begin{array}{l}\text { Setiap anggota kelompok suku saya harus } \\
\text { menguasai bahasa daerah ini }\end{array}$ & & \\
\hline
\end{tabular}

Respons terhadap dua butir pernyataan pada tabel 5 dapat sedikit memberi gambaran perihal tingginya sikap responden terhadap bahasa daerah mereka.

Berikut ini disandingkan dua tabel yang menggambarkan pengakuan responden perihal penguasaan terhadap bahasa daerah dan terhadap bahasa Indonesia.

Tabel 5.

Perbandingan Pengakuan Responden Perihal Penguasaan terhadap Bahasa Daerah dan Bahasa Indonesia

\begin{tabular}{lcc}
\multicolumn{1}{c}{ Butir Pernyataan } & $\begin{array}{c}\text { Jumlah } \\
\text { Tanggapan "ya" }\end{array}$ & $\begin{array}{c}\text { Jumlah Tanggapan } \\
\text { "tidak" }\end{array}$ \\
\hline $\begin{array}{l}\text { Saya menguasai secara baik bahasa daerah saya } \\
\text { ini }\end{array}$ & 74 & 26 \\
\hline Saya mampu berbahasa Indonesia dengan baik & 95 & 5 \\
\hline
\end{tabular}


Tabel 6 menunjukkan bahwa dari 100 orang responden, 74\%-nya mengaku menguasai secara baik bahasa daerahnya (bahasa Saleman) dan 95\%-nya mengaku mampu berbahasa Indonesia dengan baik. Itu berarti dari keseluruhan responden, lebih banyak yang mengaku menguasai/mampu berbahasa Indonesia daripada berbahasa daerah (bahasa Saleman).

\section{Vitalitas Bahasa Saleman di Negeri Saleman}

Pengolahan data kuantitatif menghasilkan nilai indeks total vitalitas bahasa Saleman di Negeri Saleman sebesar 0,50. Nilai indeks per faktor dan indeks total vitalitas bahasa Saleman di Negeri Saleman dapat dilihat pada tabel berikut ini.

Tabel 6.

Indeks Per Faktor dan Indeks Total

\begin{tabular}{l|c}
\hline \multicolumn{2}{c}{ Indeks Per Faktor dan Indeks Total } \\
\hline \multicolumn{1}{c}{ Nama Indeks } & Nilai Indeks \\
\hline indeks 1 (jumlah penutur) & 0,87 \\
\hline indeks 2 (kontak bahasa) & 0,42 \\
\hline indeks 3 (bilingualisme) & 0,57 \\
\hline indeks 4 (posisi dominan masyarakat penutur) & 0,63 \\
\hline indeks 5 (ranah penggunaan bahasa) & 0,22 \\
\hline indeks 6 (sikap bahasa) & 0,80 \\
\hline indeks 7 (regulasi) & 0,56 \\
\hline indeks 8 (pembelajaran) & 0,55 \\
\hline indeks 9 (dokumentasi) & 0,43 \\
\hline indeks 10 (respons terhadap tantangan baru) & 0,27 \\
\hline indeks total & $\mathbf{0 , 5 0}$ \\
\hline
\end{tabular}

Pada tabel di atas dapat dilihat bahwa nilai indeks kontak bahasa ialah 0,42; ranah penggunaan bahasa ialah 0,22 ; dokumentasi ialah 0,43 ; dan respons terhadap tantangan baru ialah 0,27). Keempat nilai indeks itu lebih rendah daripada nilai indeks total, yaitu lebih rendah daripada 0,50 .

Selain bahasa Saleman, di Negeri Saleman juga dituturkan bahasa Melayu Ambon dan bahasa Indonesia. Bahasa Melayu Ambon merupakan bahasa pergaulan di hampir seluruh Provinsi Maluku. Bahasa Indonesia dipakai di instansi pemerintah, di sekolah, dan di tempat ibadah. Dengan demikian, terjadi kontak bahasa antara bahasa Saleman dengan bahasa-bahasa lain yang juga dituturkan atau dipakai di Negeri Saleman itu. Perlu ditambahkan bahwa Negeri Saleman merupakan "pintu gerbang" untuk menuju ke lokasi wisata (Pantai Ora, air belanda, Pulau Tujuh). Perjalanan dari Negeri Saleman menuju Pantai Ora sekitar 15 menit dengan menggunakan perahu kecil, sedangkan obyek wisata air belanda bermuara di Teluk Saleman. Tentunya, wisatawan baik yang lewat maupun yang menginap di Negeri Saleman turut menambah intensif terjadinya kontak bahasa. Kontak bahasa itu berpengaruh terhadap 
vitalitas bahasa Saleman. Hal ini sesuai dengan yang diutarakan oleh Malabar (2015:80) bahwa pergeseran bahasa merupakan fenomena sosiolinguistik yang terjadi akibat adanya kontak bahasa. Bahkan menurut Lukman (2012:41--51), kepunahan sebuah bahasa diawali adanya pergeseran bahasa yang berlangsung dalam waktu yang relatif tidak begitu lama yang akhirnya menyebabkan pendukung sebuah bahasa beralih ke bahasa lain. Proses ini menyebabkan sebuah bahasa akan kehilangan pendukung atau penutur karena pengaruh bahasa lain yang lebih dominan atau lebih berprestise. Dalam hal ini, bahasa Melayu Ambon maupun bahasa Indonesia merupakan bahasa yang lebih dominan daripada bahasa Saleman.

Kontak bahasa mengakibatkan terjadinya bilingualisme (Chaer, 2010:84). Karena terjadi kontak bahasa antara bahasa Saleman dengan bahasa-bahasa lain yang juga dituturkan atau dipakai di Negeri Saleman itu, penutur bahasa Saleman juga menuturkan satu atau lebih bahasa yang lain. Dengan demikian dapat dikatakan bahwa orang-orang Saleman termasuk bilingual atau multilingual. Bilingualisme dan multilingualisme di Negeri Saleman itu tentu berpengaruh terhadap vitalitas bahasa Saleman. Chaer (2010:142--148) telah mengutarakan bahwa penggunaan bahasa pertama oleh sejumlah penutur dari suatu masyarakat yang bilingual atau multilingual cenderung menurun akibat adanya bahasa kedua yang mempunyai fungsi yang lebih superior. Dalam hal ini, jumlah penutur bahasa Saleman cenderung menurun akibat adanya bahasa Indonesia dan bahasa Melayu Ambon.

Bahasa Saleman di Negeri Saleman tidak digunakan dalam semua ranah. Dalam keluarga, sebagian masyarakat Saleman menggunakan bahasa Saleman, sebagian yang lain menggunakan bahasa Melayu Ambon atau bahasa Indonesia. Kebanyakan anak-anak Saleman ketika di rumah menggunakan bahasa Indonesia. Ketika orang tua berbicara kepada anaknya memakai bahasa Saleman, banyak anak menanggapinya dengan bahasa Indonesia. Dengan kata lain, banyak anak Saleman menguasai bahasa Saleman secara pasif dan tidak menguasai secara aktif. Di ranah lain yaitu di sekolah dan instansi pemerintah digunakan bahasa Indonesia. Hal ini dapat dipahami karena di antara guru, karyawan, dan pimpinan sekolah serta karyawan dan pimpinan instansi pemerintah di Negeri Saleman banyak yang berasal dari luar Negeri Saleman dan tidak dapat berbahasa Saleman. Di tempat ibadah, yaitu di masjid, penceramah atau khatib menggunakan bahasa Indonesia. Dalam pergaulan, sesama orang Saleman usia kakek nenek biasanya berkomunikasi dalam bahasa Saleman. Orang Saleman dan orang dari suku atau subsuku lain sering berkomunikasi dengan bahasa Indonesia atau bahasa Melayu Ambon. Bahasa Saleman yang tidak digunakan dalam semua ranah itu tentu berpengaruh terhadap vitalitasnya. 
Dalam hal dokumentasi, bahasa-bahasa daerah di Indonesia, apalagi bahasa yang penuturnya sedikit, termasuk bahasa Saleman, belum tertangani dengan baik. Hal ini tentu berpengaruh terhadap vitaltasnya. Dalam hubungannya dengan respons terhadap tantangan baru, bahasa-bahasa daerah di Indonesia, apalagi bahasa yang penuturnya sedikit, termasuk bahasa Saleman, juga belum tertangani dengan baik. Hal ini tentu berpengaruh terhadap vitalitasnya.

\section{PENUTUP}

Berdasarkan analisis di atas, dapat dilihat bahwa pengolahan data kuantitatif menghasilkan nilai indeks total vitalitas bahasa Saleman sebesar 0,50. Sesuai dengan kriteria vitalitas bahasa, nilai rerata 0,50 termasuk dalam rentang nilai $0,41-0,6$. Ini berarti vitalitas bahasa Saleman di Negeri Saleman termasuk dalam tingkat mengalami kemunduran. Karena vitalitas bahasa Saleman di Negeri Saleman termasuk dalam tingkat mengalami kemunduran, pihak-pihak terkait diharapkan memprioritaskan bahasa Saleman untuk dilindungi agar tingkat vitalitasnya dapat meningkat atau setidaknya tidak semakin menurun.

Empat faktor yang menentukan vitalitas bahasa, yaitu kontak bahasa, ranah penggunaan bahasa, dokumentasi, dan respons terhadap tantangan baru nilai indeksnya lebih rendah daripada nilai indeks total. Keempat faktor itulah yang menjadi penyumbang utama yang menyebabkan vitalitas bahasa Saleman di Negeri Saleman rendah, yaitu dalam posisi mengalami kemunduran. Terkait dengan kontak bahasa yang tidak dapat dihindari, pihakpihak yang peduli dan berkewajiban melindungi bahasa daerah dapat memberikan penyuluhan atau pemahaman bahwa kontak bahasa tidak selalu menggeser suatu bahasa. Bahasa-bahasa yang ada dapat menempati posisi masing-masing. Terkait dengan ranah penggunaan bahasa, pihak-pihak yang peduli dan berkewajiban melindungi bahasa daerah dapat mengusahakan penambahan ranah penggunaan atau memaksimalkan ranah penggunaan bahasa yang ada. Terkait dengan dokumentasi dan respons terhadap tantangan baru, pihak-pihak yang peduli dan berkewajiban melindungi bahasa daerah dapat mengupayakan dokumentasi yang cukup serta mengusahakan jalan agar tantangan baru dapat dihadapi dengan baik.

\section{DAFTAR PUSTAKA}

Aritonang, Buha. (2013). Vitalitas Bahasa Seget: Kajian ke Arah Pemetaan Vitalitas Bahasa Daerah. Sawerigading, 19(1), 47-56. https://doi.org/10.26499/rnh.v5i1.34

Aritonang, Buha (2016). Kriteria Vitalitas Bahasa Talondo. Ranah: Jurnal Kajian Bahasa, 5(1), 8-24. https://doi.org/10.26499/rnh.v5i1.34 
Badan Pengembangan dan Pembinaan Bahasa. (2011). Undang-Undang Republik Indonesia Nomor 24 Tahun 2009.

Candrasari, Ratri. (2017). Bahasa Devayan di Pulau Simeuleu: Kajian Vitalitas Bahasa. Disertasi Fakultas Ilmu Budaya, Unversitas Sumatera Utara.

Chaer, Abdul dan Lionie Agustina. (2010). Sosiolinguistik: Perkenalan Awal. Jakarta: Rineka Cipta.

Collins. James T. (2018). Penelitian Bahasa di Maluku. Kota Ambon: Kantor Bahasa Maluku.

Firdaus, Winci. (2018). Tekanan Kepunahan Bahasa Suwawa: Analisis Tingkat Daya Hidup Bahasa. Dalam Metalingua, 16 (2), 307-314. https://doi.org/10.26499Imetalingua.v16i2.240

Ibrahim, Gufron Ali. (2009). Metamorfosa Sosial dan Kepunahan Bahasa. Ternate: Lembaga Penerbitan Universitas Khairun (LepKhair).

Inayatusshalihah. (2018). Bahasa Buru di Pesisir Utara Pulau Buru: Sebuah Tinjauan Awal terhadap Daya Hidupnya. Dalam Forum Linguistik Universitas Gadjah Mada, 1(2), 153-161. https://doi.org/10.22146/db.v1i2.332

Katubi. (2011). Bahasa Minoritas dan Konstruksi Identitas Etnik pada Komunitas Bahasa Kui di Alor, Nusa Tenggara Timur. Masyarakat Indonesia, 37(2), 199-219.

Lukman. (2012). Vitalitas Bahasa: Pergeseran dan Pemertahanan Bahasa. Makassar: de La Macca.

Malabar, Sayama. (2015). Sosiolinguistik. Gorontalo: Ideas Publishing.

Mardikantoro, Hari Bakti. (2012). Bentuk Pergeseran Bahasa Jawa Masyarakat Samin dalam Ranah Keluarga. Litera, 11(2). https://doi.org/10.21831/1tr.v11i2.1062

Maricar, Farida dan Ety Duwila (2017). Vitalitas Bahasa Ternate di Pulau Ternate. Etnohistori, 4(2), 136-151.

Nugroho, Mardi. (2018). Vitalitas Bahasa Yalahatan. Makalah pada Prosiding Seminar Bahasa dan Sastra. Bandar Lampung: Kantor Bahasa Provinsi Lampung.

Sahril. (2018). Pergeseran Bahasa Daerah pada Anak-Anak di Kuala Tanjung, Sumatra Utara. Ranah: Jurnal Kajian Bahasa, 7(2), 210 -228. https://doi.org/10.26499/rnh.v7i2.571

Setiawati dkk. (2019). Vitalitas Bahasa, Diglosia, dan Ketirisannya: Pemertahanan Bahasa Manduro di Desa Manduro, Kecamatan Kabuh, Kabupaten Jombang, Jawa Timur. Widyaparwa, 47(2), 116-127. https://doi.org/10.26499/wdprw.v47i2.293

Tim Konservasi dan Revitalisasi. (2017). Pedoman Konservasi dan Revitalisasai Bahasa. Jakarta: Badan Pengembangan dan Pembinaan Bahasa

Tim Pemetaan Bahasa. (2017). Bahasa dan Peta Bahasa di Indonesia. Jakarta: Badan Pengembangan dan Pembinaan Bahasa

Unesco. (2011). UNESCO's Languages Vitality and Endangerment Methodological Guideline: Review of Application and Feedback since 2003.

Wagiati, Wahya, dan Riyanto (2017). Vitalitas Bahasa Sunda di Kabupaten Badung. Litera, 16. (2), 309-317. https://doi.org/10.21831/ltr.v16i2.14357

Wibowo, Sarwo F. (2014). Vitalitas Bahasa Enggano di Pulau Enggano. Ranah: Jurnal Kajian Bahasa, 3(1), 1-12. https://doi.org/10.26499/rnh.v3i1.6

Winarti, Sri. (2014). Vitalitas Bahasa Bahonsuai di Desa Bahonsuai, Provinsi Sulawesi Tengah. Widyaparwa, 42(1), 61-74. 